DOI 10.31558/2307-2318.2021.4.22

УДК 338.488 .3

JEL: D01; Z32

Солоненко Ю. В.

к.е.н., доцент кафедри підприємництва, корпоративної та просторової економіки, Донецький національний університет імені Василя Стуса

ORCID: 0000-0003-1696-2151

u.solonenko@donnu.edu.ua

\title{
ФЕСТИВАЛІ ВУЛИЧНОї ЇЖІ ЯК ЕЛЕМЕНТ ТУРИСТИЧНОЇ ДЕСТИНАЦІї
}

Для багатьох світових економік сфера туризму $\epsilon$ одним із головних пріоритетів, адже надходження до бюджетів від неї знаходяться на доволі високому рівні. Гастрономічний туризм у світі та в Україні, зокрема, набирає все більшу популярність серед різних категорій туристів. $У$ статті досліджено та проаналізовано особливості фестивалів вуличної їжі як елементу туристичної дестинації в сучасних умовах економічного розвитку. Обгрунтовано необхідність наукового дослідження заявленої тематики. Дестинації ми розглядаємо як локаџійні об'єкти, які володіють туристично-рекреачійними ресурсами, доступними завдяки наявності необхідної інфраструктури, щзо доводяться до споживача у формі сформованого та підготовленого до продажу туристичного продукту сучасними засобами маркетингових комунікаиій у системі важелів інтегрованого управління суб'єктами господарювання. Гастрономічний туризм позиціонується нами як чинник соиіально-економічного розвитку територій. Простежено розвиток та особливості фукиіонуваня відомих світових фестивалів їжі: Bacon Fest (м.Сакраменто, США), Фестиваль їжі та вина (м.Мельбурн, Австралія ), Реixe em Lisboa (Португалія), Brussels Food Truck Festival (м.Брюссель, Бельгія), Pizzafest (м.Неаполь, Imaлія), Taste of Chicago (м.Чикаго,США), Fiesta del Marisco (м.О-Грове, Icnaнiя), Salon du chocolat (м.Париж, Франиія), Ribfest Торонто (Канада), Foodies Festival Брайтон (Великобританія) та ін. Підкреслено вплив гастрономічного туризму на формування бренду туристичного місия, в просторових межах якого він відбувається. Визначено основні характеристики життєвого изиклу та виявлено фактори, які впливають на стадії розвитку фестивалів вуличної їжі в контексті туристичної дестиначії. Отжже, фестивалі вуличної іжі не тільки долучають туристів до гастрономічних надбань краю, але й сприяють ознайомленню з культурно-історичними, соціальними, економічними, археологічними особливостями регіону.

Ключові слова: фестиваль вуличної їжі, туристична дестинація, життєвий ичкл дестинації, гастрономічний туризм.

Рис.1,Табл. 1., Літ. 8.

Постановка проблеми. На сучасному етапі розвитку туристичної сфери потреби туристів щоразу максиміалізуються. Одним 3 пріоритетних шляхів задоволення потреб клієтів туристичної спрямованості $\epsilon$ створення дестинацій. Дестинації ми розглядаємо як локаційні об'єкти, які володіють туристичнорекреаційними ресурсами, доступними завдяки наявності необхідної інфраструктури, що доводяться до споживача у формі сформованого та підготовленого до продажу 
туристичного продукту сучасними засобами маркетингових комунікацій у системі важелів інтегрованого управління суб'єктами господарювання. Фестивалі вуличної їжі у світі та в Україні, зокрема, набирають все більшу популярність серед різних груп туристів. За даними Європейської бізнес асоціації (СБА) на частку креативної економіки припадає 3,4\% світового ВВП, що становить майже 1,6 трильйонів доларів США.

Аналіз останніх досліджень і публікацій. Дослідженням туристичних дестинацій та закономірностями їх розвитку займались такі вітчизняні та зарубіжні вчені як: Є. Аленова, В. Альтхоф, В. Боголюбов А. Бусигін, А. Головчан, Л. Кірьянова, А. Расулова, Д. Беліво, Д. Гетца, Д. Гільберта, Р. Лінча, Дж Рітчі, А. Віла та інші.

Постановка завдання. На основі викладеного вище, можна сформулювати завдання дослідження, яке полягає у виявленні особливостей організації фестивалів вуличної їжі як елементу туристичної дестинації, аналізі функціонування існуючих світових фестивалів вуличної їжі, визначення життєвого циклу фестивалю та факторів впливу на подальший розвиток туризму в Україні та світі.

Результати дослідження. Дестинація - місце, куди в цей час прямують люди або речі, трактується відповідно до Оксфордського словника понять і термінів, за редакцією С. Медліка. Головним місцем локалізації туристичної діяльності, яке може бути як країною, регіоном, містом або іншою територіією, яка приваблює туристів та має максимальну концентрацію визначних туристичних пам'яток, засобів розміщення, харчування, розваг, інших послуг та економічного, соціального і фізичного впливу туризму [1].

У новій редакції Закону України «Про туризм» зазначається, що «дестинація (туристична) - місце призначення туристичної подорожі (туристичної поїздки, туру, екскурсіі), місце відвідування (територія, місцевість, місто, населений пункт, туристичний центр) особами, які не проживають постійно в даній місцевості і не належать до категорії місцевого населення» [2].

United Nations World Tourism Organization (Всесвітня туристична організація) вважає туристичну дестинацію як основне місце призначення туристичної поїздки, територію, відвідання якої посідає центральне місце всієї подорожі. Фізичний простір, де турист проводить не менше одного дня та включає в себе послуги, туристичні продукти, ресурси, різні пам'ятки та має фізичні та адміністративні межі, що визначають форму iii управління, а також імідж і репутацію, які впливають на іiі конкурентоспроможність на туристичному ринку є місцевою туристичною дестинацією [3].

Всесвітня асоціація гастрономічного туризму визначає гастрономічний туризм як подорожі 3 метою отримання аутентичного досвіду, заснованого на культурі споживання їжі або напоїв; відкритті унікальних місць та їхньої культури через національну кухню [4].

Латинські поняття «feast» та «festival» спочатку були тотожними і означали буквально «свято». Упродовж еволюційних перетворень «feast» закріпилося за релігійними святами, а «festival» набуло сучасного значення, зберігши обов'язковий елемент святковості та урочистості. Однак фестиваль відрізняється від свята як такого, по-перше обов'язковою присутністю тематики, i, по-друге, - наявністю певного суб'єкта-організатора, одного або декількох осіб.

Фестиваль вуличної їжі - це подія на визначеній території, яка об’єднує різні групи людей з приводу однієї визначеної тематики їжі, напоїв та передає культуру споживання, відпочинку і отримання задоволення від життя. Такі фестивалі $є$ важливою компонентою туристичної індустрії та невід'ємною складовою культури, що формує 
національний колорит, визначає ступінь привабливості території для туристів. Це перспективний вид туризму, що з'явився порівняно недавно та динамічно розвивається у світі та в Україні, зокрема. У світі безліч гастрономічних фестивалів, деякі 3 них присвячені фірмовій страві регіону (як, наприклад, піца в Неаполі або морепродукти в Португалії), а під час інших можна оцінити працю кухарів 3 усього світу. Кращі ресторани і пікніки на галявині, стрітфуд і висока кухня, а також музика, спілкування і веселощі (табл. 1).

Найвідоміші фестивалі вуличної їжі у світі *

Таблиця 1

\begin{tabular}{|c|c|c|c|c|}
\hline № & Назва & $\begin{array}{c}\text { Місце } \\
\text { проведення }\end{array}$ & $\begin{array}{c}\text { Головна ідея та особливості } \\
\text { проведення }\end{array}$ & Період \\
\hline 1. & Bacon Fest & $\begin{array}{l}\text { м.Сакраменто, } \\
\text { США }\end{array}$ & $\begin{array}{l}\text { Понад } 100 \text { шеф-кухарів } 3 \text { Америки і } \\
\text { Свропи готують під час Бекон Фесту } \\
\text { різноманітні страви } 3 \text { фермерської } \\
\text { свинини, вирощеної на території } \\
\text { штату Каліфорнія. Бекон присутній у } \\
\text { всіх стравах, приготованих під час } \\
\text { фестивалю, навіть в десертах. У } 2017 \\
\text { році особливою популярністю } \\
\text { користувалися салат з бекону, рамен } \\
3 \text { локшиною з бекону і морозиво } 3 \\
\text { нього ж. Крім усіляких страв зі } \\
\text { свинини відвідувачів чекають } \\
\text { змагання шеф-кухарів, майстер- } \\
\text { класи, відмінне крафтового пиво і } \\
\text { жива музика. }\end{array}$ & лютий \\
\hline 2. & $\begin{array}{l}\text { Фестиваль } \\
\text { їжі та вина }\end{array}$ & $\begin{array}{l}\text { м.Мельбурн, } \\
\text { Австралія }\end{array}$ & 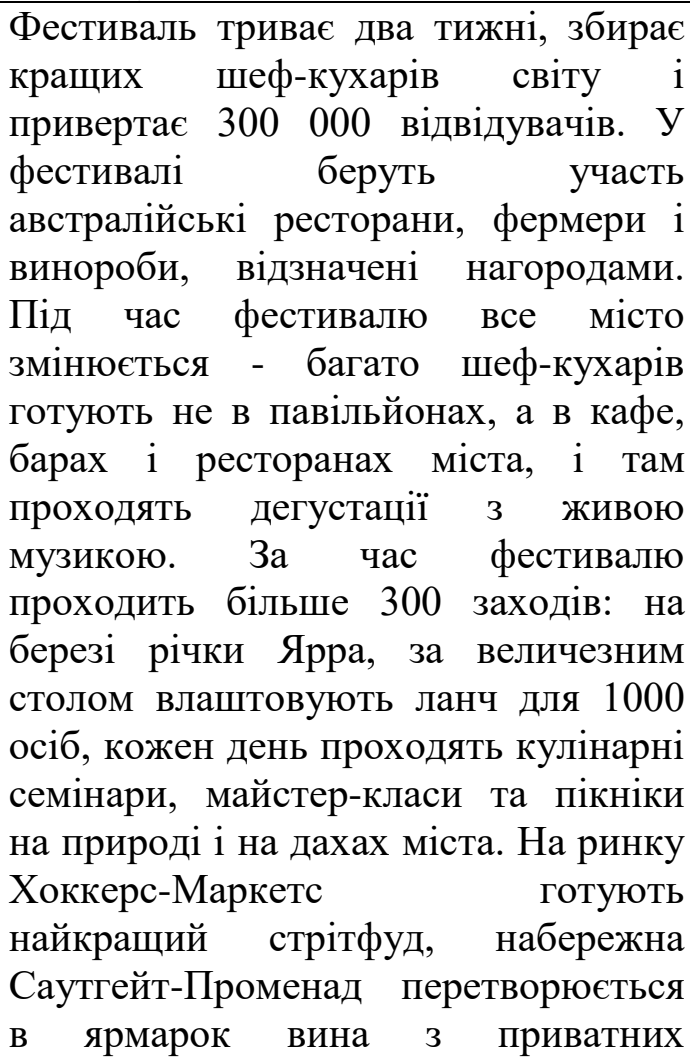 & березень \\
\hline
\end{tabular}




\begin{tabular}{|c|c|c|c|c|}
\hline & & & $\begin{array}{l}\text { виноробень, а в Королівському } \\
\begin{array}{l}\text { виставковому } \\
\text { Exhibition Building) }\end{array} \\
\begin{array}{l}\text { урочисті вечері. } \\
\text { проходять }\end{array}\end{array}$ & \\
\hline 3. & $\begin{array}{l}\text { Peixe em } \\
\text { Lisboa }\end{array}$ & Португалія & 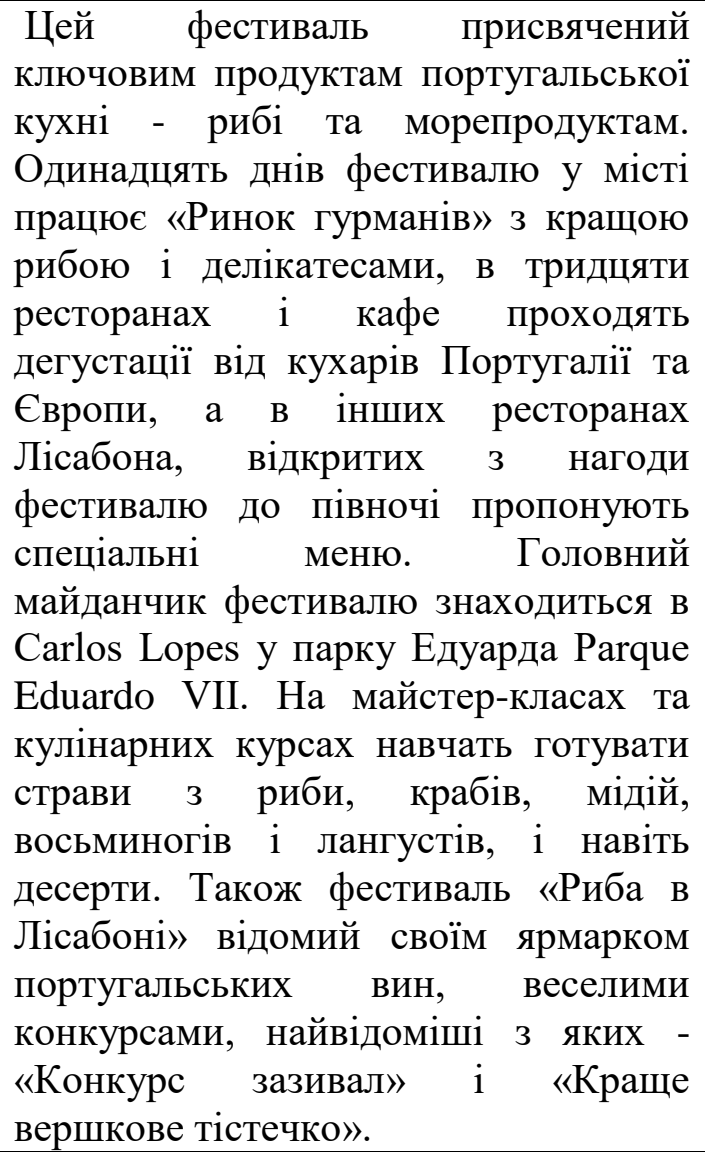 & квітень \\
\hline 4. & $\begin{array}{l}\text { Brussels } \\
\text { Food Truck } \\
\text { Festival }\end{array}$ & $\begin{array}{l}\text { м.Брюссель, } \\
\text { Бельгія }\end{array}$ & 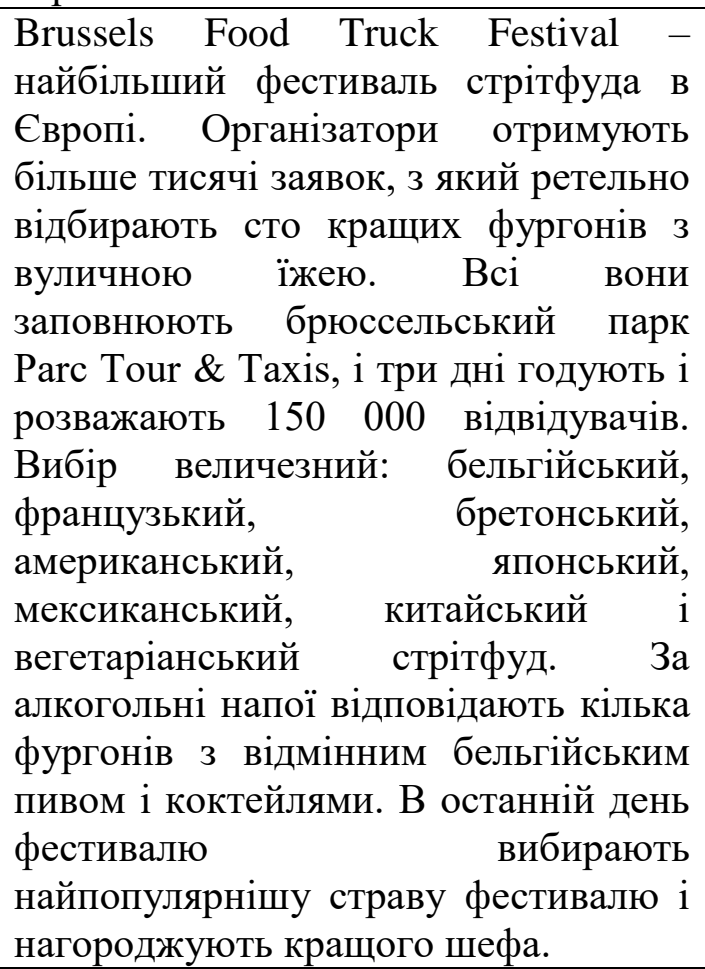 & червень \\
\hline
\end{tabular}




\begin{tabular}{|c|c|c|c|c|}
\hline 5 . & Pizzafest & $\begin{array}{l}\text { м.Неаполь, } \\
\text { Італія }\end{array}$ & 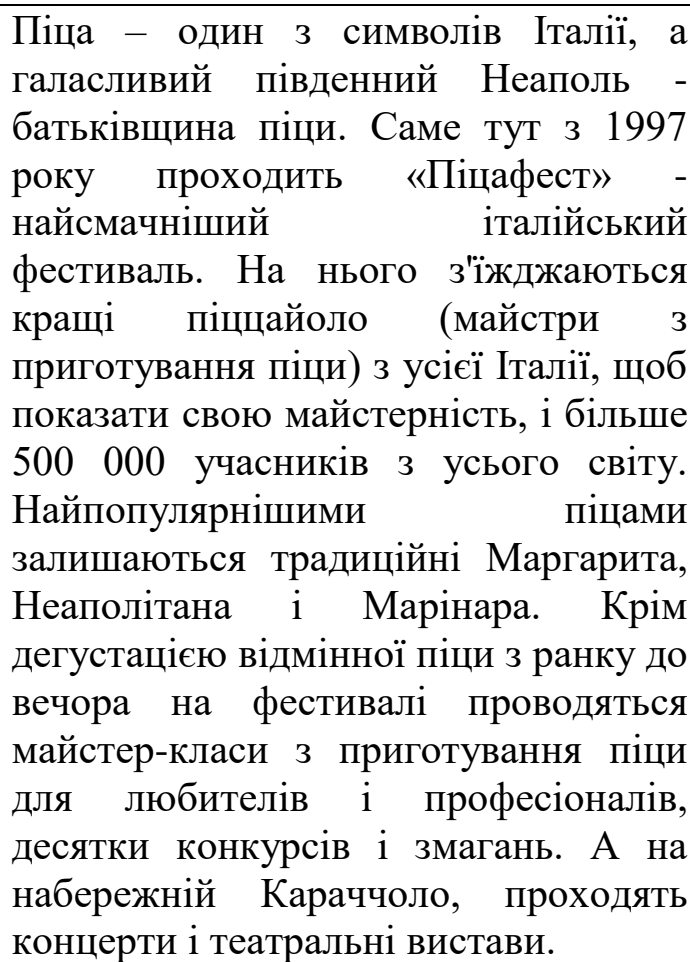 & червень \\
\hline 6. & $\begin{array}{l}\text { Taste of } \\
\text { Chicago }\end{array}$ & $\begin{array}{l}\text { м.Чикаго, } \\
\text { США }\end{array}$ & $\begin{array}{l}\text { «Смак Чикаго» - один } 3 \text { найбільших } \\
\text { фестивалів їжі у світі. Він } \\
\text { проводиться } 31980 \text { p. і привертає } \\
\text { увагу більше } 3 \text { млн осіб. У фестивалі } \\
\text { беруть участь ресторани Чикаго, Лос- } \\
\text { Анджелеса, Нью-Йорка, } \\
\text { американські і європейські шеф- } \\
\text { кухарі та кондитери. Фестиваль } \\
\text { проходить під відкритим небом в } \\
\text { Грант-Парку (Grant Park) в самому } \\
\text { центрі міста. Площа парку заставлена } \\
\text { палатками та тентами, де готують і } \\
\text { дегустують сотні страв і проводять } \\
\text { майстер-класи для дітей і дорослих. } \\
\text { Вибір страв величезний - класичні } \\
\text { американська кухня і стрітфуд, } \\
\text { національні кухні народів світу: } \\
\text { італійська, мексиканська, ірландська, } \\
\text { французька, африканська, китайська. } \\
\text { Найпопулярніші страви: піца по- } \\
\text { чиказьки, тако, чиказькі хот-доги і } \\
\text { барбекю, чізкейк Елліс, морозиво і } \\
\text { різні десерти. Крім дегустацій на } \\
\text { фестивалі є майстер-класи, курси та } \\
\text { лекції для дорослих, конкурси та } \\
\text { атракціони для дітей. «Смак Чикаго» } \\
\text { славиться своїми концертами, на } \\
\text { яких виступають відомі артисти. }\end{array}$ & липень \\
\hline
\end{tabular}




\begin{tabular}{|c|c|c|c|c|}
\hline 7. & $\begin{array}{l}\text { Fiesta del } \\
\text { Marisco }\end{array}$ & $\begin{array}{l}\text { м.О-Грове } \\
\text { Іспанія }\end{array}$ & 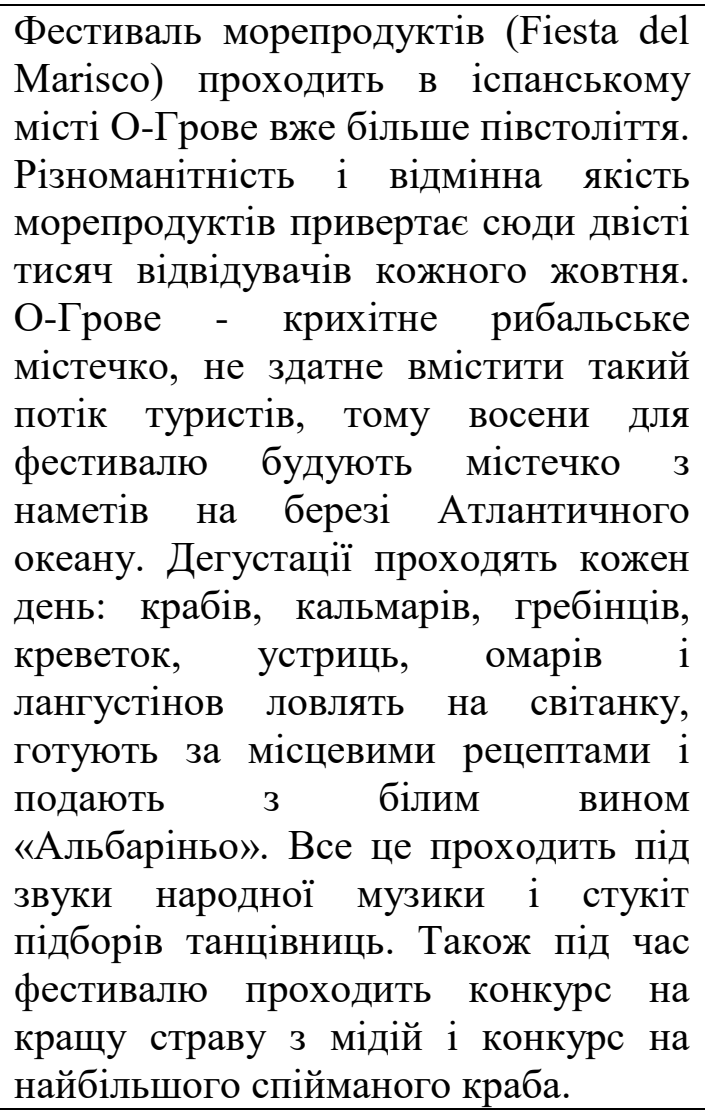 & жовтень \\
\hline 8 . & $\begin{array}{l}\text { Salon du } \\
\text { chocolat }\end{array}$ & $\begin{array}{l}\text { м.Париж, } \\
\text { Франція }\end{array}$ & $\begin{array}{l}\text { Перший фестиваль } \\
\text { пройшов в } 1922 \text { році в Парижі, і з тих } \\
\text { пір набрав величезну популянність: } \\
\text { тепер такі фестивалі проводяться в } \\
29 \text {-ти містах по всьому світу. } \\
\text { Паризький фестиваль шоколаду } \\
\text { об'єднує } 9 \text { } 000 \text { учасників і } 7 \\
\text { мільйонів відвідувачів. Крім цукерок } \\
\text { і шоколаду з усього світу за тисячами } \\
\text { різноманітих рецептів, під час } \\
\text { фестивалю є можливість спробувати } \\
\text { десерти від кращих кондитерів } \\
\text { Парижа. Виставковий простір } \\
\text { розділено на дві зони - одна для } \\
\text { дегустаторів, інша для професіоналів, } \\
\text { такожє бібліотека шоколаду, відділ } 3 \\
\text { стрітфудом, дитяча кімната. Під час } \\
\text { фестивалю проводяться лекції та } \\
\text { майстер-класи, а також модний } \\
\text { показ, під час якого моделі } \\
\text { демонструють одяг, зроблений з } \\
\text { шоколаду. }\end{array}$ & $\begin{array}{l}\text { листопа } \\
\text { д }\end{array}$ \\
\hline 9. & Ribfest & $\begin{array}{l}\text { м.Торонто, } \\
\text { Канада }\end{array}$ & $\begin{array}{l}\text { Торонто «Рібфест» - це спосіб } \\
\text { відправитися влітку в Канаду. } \\
\text { Щороку захід проводиться під час }\end{array}$ & липень \\
\hline
\end{tabular}




\begin{tabular}{|c|c|c|c|c|}
\hline & & & $\begin{array}{l}\text { святкування дня Канади в Centennial } \\
\text { Ранk і привертає більше } 150000 \\
\text { чоловік. } 3 \text { усією Північної Америки } \\
\text { з'їжджаються «ribbers» щоб показати } \\
\text { своє вміння в приготуванні реберець } \\
\text { - барбекю, і в надії авоювати титул } \\
\text { кращого «ribbers» Канади. Якщо ви } \\
\text { не любите барбекю, то є багато } \\
\text { iнших продуктів на вибір: «kettle } \\
\text { corn, pulled pork, blooming onions», i } \\
\text { також багато пива і розваг! Але } \\
\text { «Рібест» не тільки для дорослих; є } \\
\text { також дитячі заходи, такі як } \\
\text { карнавальні ігри, чарівні шо, } \\
\text { малювання особи. Це чудове свято } \\
\text { для усіх вікових груп, який } \\
\text { закінчується красивим показом } \\
\text { феєрверків у День Канади. }\end{array}$ & \\
\hline 10. & $\begin{array}{l}\text { Foodies } \\
\text { Festival }\end{array}$ & $\begin{array}{l}\text { м.Брайтон, } \\
\text { Великобритані } \\
\text { я }\end{array}$ & 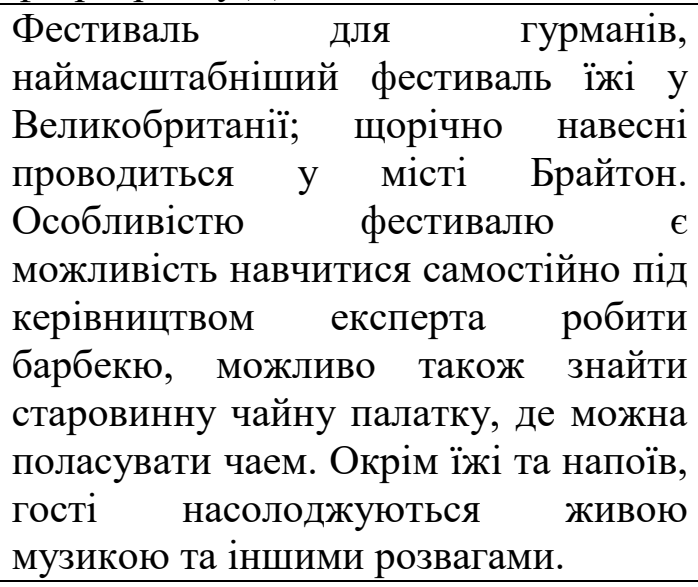 & $\begin{array}{l}\text { квітень- } \\
\text { травень }\end{array}$ \\
\hline 11. & $\begin{array}{l}\text { Great } \\
\text { Wisconsin } \\
\text { Cheese } \\
\text { Festival }\end{array}$ & $\begin{array}{l}\text { м.Вісконсин, } \\
\text { США }\end{array}$ & 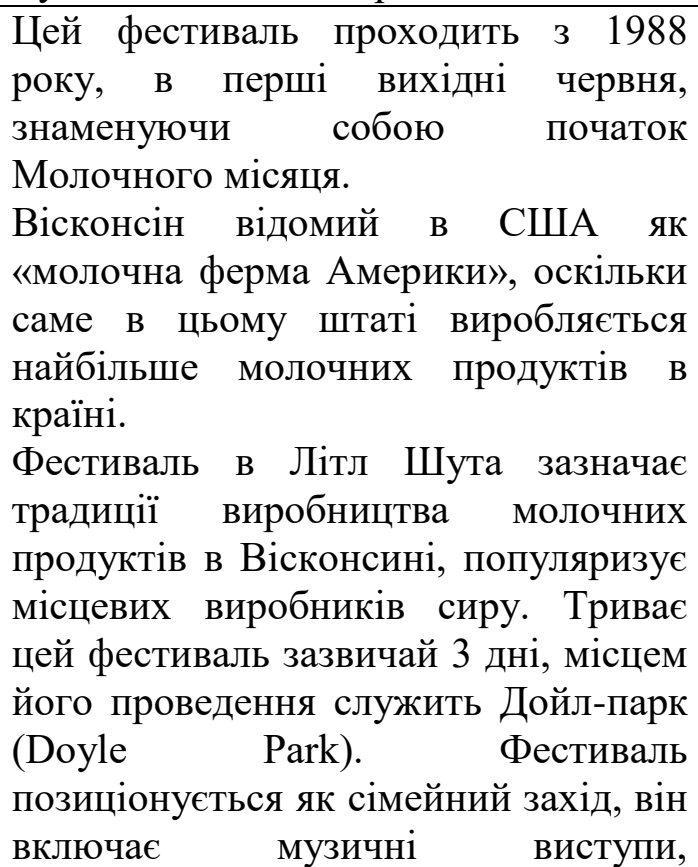 & \\
\hline
\end{tabular}




\begin{tabular}{|c|c|c|c|c|}
\hline & & & $\begin{array}{l}\text { спеціальний Великий сирний парад, } \\
\text { сирні дегустації, демонстрації } \\
\text { карвінгу, конкурс чізкейків, змагання } \\
3 \text { поїдання сиру, скачки, дитячі ігри } \\
\text { та ще безліч інших розваг. }\end{array}$ & \\
\hline 12. & $\begin{array}{l}\text { Vegetarian } \\
\text { Festival }\end{array}$ & Бангкок & $\begin{array}{l}\text { Протягом дев'яти днів відбувається } \\
\text { вегетаріанський } \\
\text { присвячений дестиваль, } \\
\text { Імператора. Тут ви можете знайти } \\
\text { людей, які торгують широким } \\
\text { асортиментом вегетаріанських страв, } \\
\text { включаючи локшину, торти і багато } \\
\text { іншого. Одна з найдивніших частин } \\
\text { фестивалю - підроблене м'ясо. Деякі } \\
\text { з видів такого м'яса виглядають як } \\
\text { справжні, а деякі не можуть } \\
\text { претендувати на це. С тофу- ковбаси } \\
\text { і багато простої їжі. Щоночі під час } \\
\text { фестивалю ви зможете побачите } \\
\text { ліхтарі і запалені свічки, а також } \\
\text { виступи китайської опери. }\end{array}$ & жовтень \\
\hline 13. & $\begin{array}{l}\text { Epcot } \\
\text { Internationa } \\
1 \text { Food and } \\
\text { Wine } \\
\text { Festiva }\end{array}$ & США & $\begin{array}{l}\text { Двомісячний захід проводиться } \\
\text { щорічно в парку Walt Disney World, } \\
\text { Ерсот. У ньому є «World Showcase», } \\
\text { де представлені } 11 \text { країн, включаючи } \\
\text { Італію, Японію i Марокко. У } \\
\text { кожному павільйоні ви можете } \\
\text { знайти їжу, напої, цукерки, одяг і } \\
\text { сувеніри відмінної якості з країни, } \\
\text { представленої на фестивалі. Крім } \\
\text { гарної їжі, проводиться серія } \\
\text { концертів «Еаt to the Beat», майстер- } \\
\text { класи від відомих шеф-кухарів. }\end{array}$ & $\begin{array}{l}\text { Червень } \\
\text {-липень }\end{array}$ \\
\hline 14. & $\begin{array}{l}\text { The Good } \\
\text { Food and } \\
\text { Wine Show }\end{array}$ & $\begin{array}{l}\text { Південна } \\
\text { Африка }\end{array}$ & $\begin{array}{l}\text { На фестивалі Good Food and Wine } \\
\text { Show, що проводиться щороку в } \\
\text { Південній Африці, представлено } \\
\text { близько } 200 \text { експонатів, кожен з яких } \\
\text { демонструє останні тенденції в галузі } \\
\text { продуктів харчування, напоїв, a } \\
\text { також інноваційних домашніх } \\
\text { гаджетів. Проводяться також } \\
\text { двогодинні майстер-класи з відомими } \\
\text { шеф-кухарями, як на багатьох } \\
\text { кращих фестивалях. Але одна дійсно } \\
\text { крута і унікальна річ в цьому } \\
\text { фестивалі -це презентація здорового } \\
\text { способу життя. }\end{array}$ & липень \\
\hline
\end{tabular}




\begin{tabular}{|c|c|c|c|c|}
\hline 15. & $\begin{array}{l}\text { Abergavenn } \\
\text { y Food } \\
\text { Festival }\end{array}$ & $\begin{array}{l}\text { Абергавенні, } \\
\text { Великобритані } \\
\text { я }\end{array}$ & 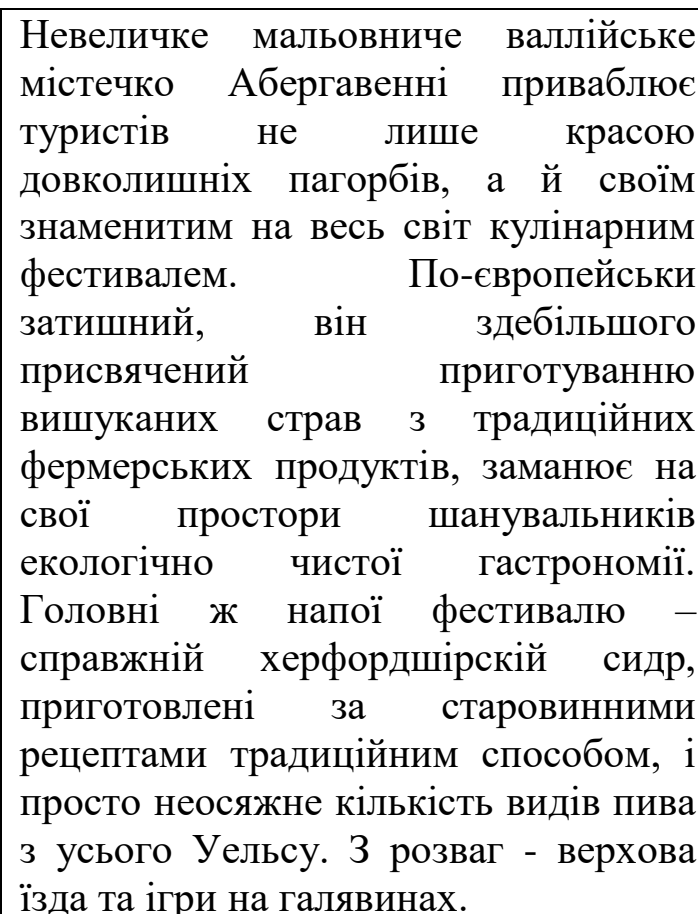 & вересень \\
\hline
\end{tabular}

Складено автором на основі контент-аналізу з Інтернет-джерел.

Розглядаючи фестивалі вуличної їжі як елемент туристичної дестинації, необхідно означити життєвий цикл події та фактори, що впливають на формування розвитку даної індустрії, враховуючи багатоаспектність події та участь багатьох суб'єктів.

Модель життєвого циклу фестивалю вуличної їжі як туристичної дестинації представлено на (рис. 1).

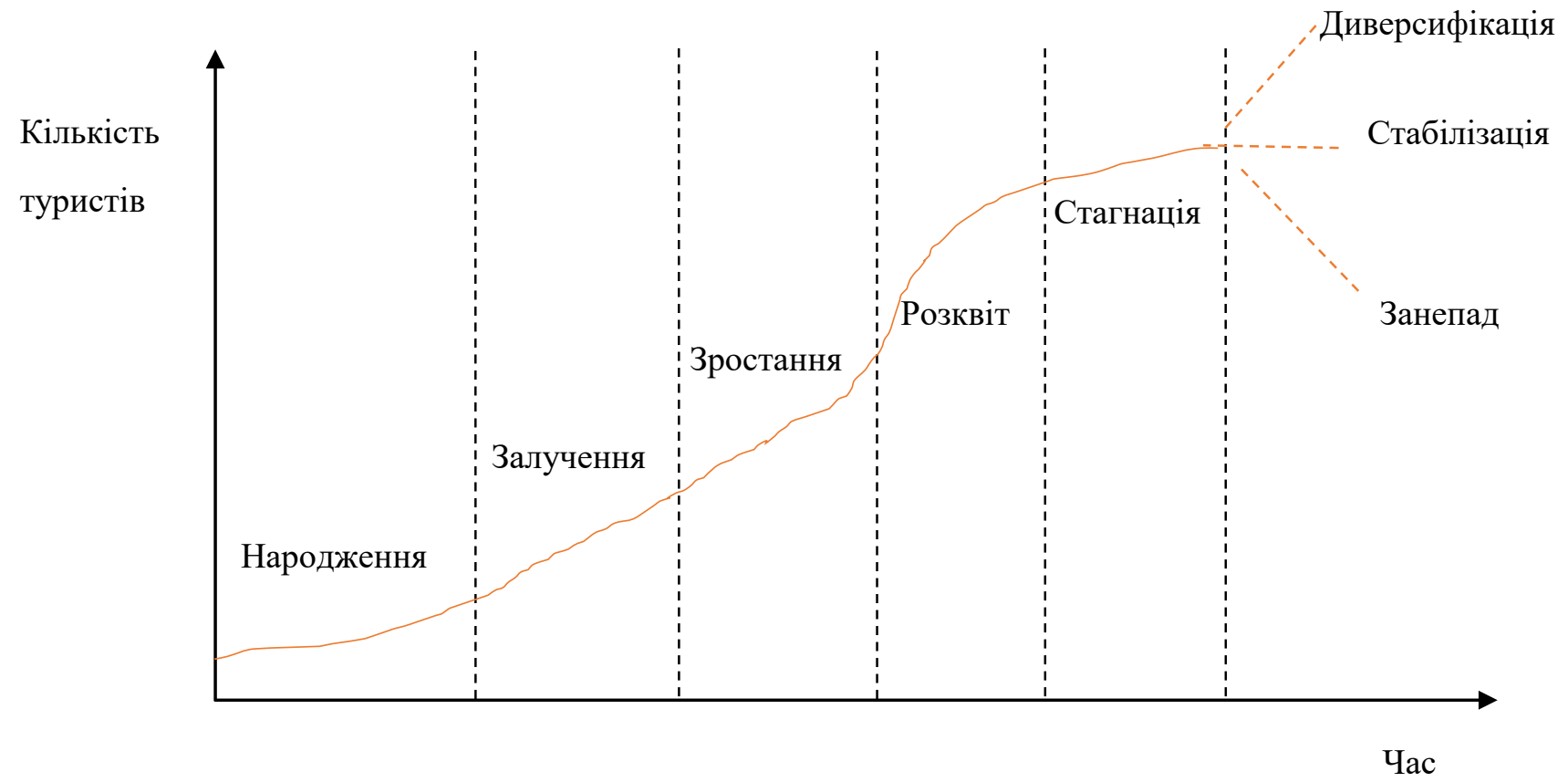

Рисунок 1 - Модель життєвого циклу фестивалю вуличної їжі 
Модель відображає п'ять основних стадій розвитку фестивалю вуличної їж та одну стадію, від якої буде залежати майбутній розвиток подій.

Стадія «Народження» характеризується початком діяльності організаторів фестивалю та проведенням першої події. Основна цільова аудиторія - мешканці прилеглої території та незначна кількість туристів, які, можливо, опинились там випадково або, як наслідок приїхали на тривалий термін у визначене місце, та 3 цікавості відвідали фестиваль вуличної їжі. Ця стадія характеризується мобільною комунікацією між суб'єктами, організатори мають можливість одразу реагувати на запити ринку, процес ухвалення рішень простий і швидкий.

Стадія «Залучення» має на меті проведення фестивалів із залученням партнерів, що зможуть обслуговувати туристів і допоможуть організувати приємний прийом. У свою чергу, такі дії стимулюють створення туристичної інфраструктури, формують туристичний ринок та створюється відповідно сезонність проведення фестивалів. Цільова аудиторія збільшується та маркетингова стратегія міцнішає за рахунок партнерської мережі.

Стадія «Зростання». Відбувається укріплення позицій, перехід від спонтанного управління до формальної організаційної та управлінської структури фестивалю. Дестинація демонструє швидке зростання індустрії туризму, до партнерства залучаються великі туроператорські компанії, міжнародні готелі та інші компанії, дотичні до туристичної сфери. Аналіз цільової аудиторії, як правило, відображає походження туристів з різних куточків світу.

Стадія «Розквіт» характеризується розвитком процесів формалізації та контролю, радикальними змінами у діяльності фестивалю, передусім, це стосується процесів контролю та адміністрування. На цьому етапі формуються чітка організаційна структура, системи управління бізнес-процесами, принципи та механізми комунікації між командою фестивалю та споживачами (туристами). Туризм стає основною дохідною частиною фестивалю вуличної їжі та дотичних партнерів, проте сповільнюється темп зростання туристичних прибутків. Екологічне, соціальне та економічне навантаження на дестинацію вище за їі пропускну спроможність, кількість туристів перевищує чисельність місцевого населення. Готелі, хостели та інші види нерухомості, котра здається в оренду $є$ переповненими, якість сервісу постійно знижується.

Стадія «Стагнації» демонструє те, що туристи втрачають інтерес до діючого фестивалю вуличної їжі через ряд зовнішніх та внутрішніх чинників, відповідно прибутки від туристів не поступають. У команди фестивалю виникає ряд труднощів та викликів:

- можливість критичних непорозумінь між партнерами-засновниками фестиваалю;

- формалізація політики та структури управління, що зменшує швидкість комунікації;

- збільшення адміністративного контролю та зменшення креативності;

- зменшення інвестицій;

- наявність прихованих проблем та протиріч у команді, що ускладнює управління.

Вихід із ситуації полягає у вирішенні та подолані проблем (стадія стабілізація, диверсифікація) або ж закритті справи і настає стадія «Занепад». 
Враховуючи вищезазначені особливості життєвого циклу, виділимо фактори, що будуть впливати на процес управління фестивалем вуличної іжі як елементом туристичної дестинації та мати право на прийняття рішень:

- внутрішні інтенціональні фактори - дії, які навмисно ініціюються організаторами фестивалю або партнерами, спрямовані на покращення умов, інфраструктури, іміджу та іншого. До них можливо віднести маркетингову компанію, реконструкцію готелів, хостелів, створення парку автобусних перевезень до місця дестинації та інше;

- зовнішні неінтенціональні фактори - є непередбаченими, суб'єкт, що має право приймає рішення не має на них впливу;

- зовнішні інтенціональні фактори - організатори фестивалю не є напряму причетними, але їхні дії спровокували навмисні ініціативи, що можуть стати як позитивним так, і негативним чинником, наприклад, поява конкурента на діючому ринку.

Сфера туризму у світі за останні п’ять років (до COVID-19) демонструє позитивну тенденцію до зростання і фестивалі вуличної їжі відіграють у цьому процесі свою важливу роль. Для українців легко подорожувати стало можливо після підписання угоди про безвізовий режим України з СС у Страсбурзі 17 травня 2017 року. Україна у 2019 році посіла 78 місце серед 136 держав світу за T\&T competitiveness index (Індекс конкурентоспроможності у сфері подорожей i туризму). Зазначений індекс розраховується на основі 15 факторів: бізнес-середовище, безпека, охорона здоров'я і гігієна, людські ресурси та ринок праці, ціни, інфраструктура, природні, культурні ресурси і т.д. Країна показала самий високий темп росту в субрегіоні, піднявшись за два роки на 10 пунктів. Для багатьох світових економік туризм є одним із головних пріоритетів, адже надходження до бюджетів від неї знаходяться на доволі високому рівні.

Висновки. Економіка туризму становить 30\% світового експорту послуг, на який припадає $10 \%$ світового ВВП та 7\% світового експорту товарів і послуг, посідає третє місце в світі як категорія експорту за даними ООН. У 2016 році аналітики підрахували, що туристи витратили близько 1220 мільярдів доларів США на харчування, проживання, розваги, шопінг та інші послуги, пов'язані з туристичною діяльністю. Відповідно до проведеного аналізу, можемо константувати, що відомі світові фестивалі вуличної їжі є невід'ємною складовою туристичних дестинацій, які відвідують сотні людей щороку. Для України подібна тенденція ще не є масовою, проте проведення подібних заходів вже існує. Можливість оцінити та проаналізувати зарубіжний досвід у аспектах прогнозування та врахування різних факторів, що впливають на розвиток фестивалів вуличної їжі як елементу туристичної дестинації, а також постійний моніторинг, дасть можливість реалізувати привабливу індустрію для вітчизняних та іноземних туристів в Україні.

\section{СПИСОК ВИКОРИСТАНИХ ДЖЕРЕЛ}

1. Оксфордський словник понять i термінів. URL: https://www.oxfordreference.com

2. Закон України «Про туризм». URL: http://zakon1.rada.gov.ua/cgi-
bin/laws/main.cgi

3. UNWTO World Tourism Barometer. Edition 2016. URL: 
4. Офіційний сайт всесвітної асоціація гастрономічного туризму. URL: http://www.worldfoodtravel.org

5. Офіційний сайт Глобальної асоціації гастрономічного туризму. URL: https://www.globalfoodtourism.com

6. Драчева Е. Л. Гастрономический туризм: современные тенденции и перспективы. URL:http://cyberleninka.ru/article/n/gastronomicheskiy-turizmsovremennyetendentsii-i-perspektivy

7. Бусигін А. П. Як організувати кулінарний туризм? Готельний і ресторанний бізнес. 2016. N 2. С. 74-76.

8. Расулова А.М. Потенціал ресторанного бізнесу у розвитку гастрономічного туризму України. Економіка та держава. 2015. № 5. С. 78-83.

\section{REFERENCES}

1. Oksfordskyi slovnyk poniat i terminiv. URL: https://www.oxfordreference.com

2. 3akon Ukraïny «Pro turyzm». URL: http://zakon1.rada.gov.ua/cgibin/laws/main.cgi

3. UNWTO World Tourism Barometer. Edition 2016. URL: http://unwto.org/facts/eng/barometer.htm.

4. Ofitsiy̆nyy̆ say̆t vsesvitnoi asotsiatsiia hastronomichnoho turyzmu. URL: http://www.worldfoodtravel.org

5. Ofitsiy̆nyy̆ say̆t Hlobalnoï asotsiatsiï hastronomichnoho turyzmu. URL: https://www.globalfoodtourism.com

6. Dracheva E. L. Hastronomichnyy̆ turyzm: suchasni tendentsiï i perspektyvy. URL: http://cyberleninka.ru/article/n/gastronomicheskiy-turizmsovremennye- tendentsii-iperspektivy

7. Busyhin A. P. Yak orhanizuvaty kulinarnyy̆ turyzm? Hotelnyy̆ i restorannyy̆ biznes. 2016. No 2. S. 74-76.

8. Rasulova A.M. Potentsial restorannoho biznesu u rozvytku hastronomichnoho turyzmu Ukraïny. Ekonomika ta derzhava. 2015. No 5. S. 78-83.

\section{Солоненко Ю. В. \\ ФЕСТИВАЛИ УЛИЧНОЙ ЕДЫ КАК ЭЛЕМЕНТ ТУРИСТИЧЕСКОЙ ДЕСТИНАЦИИ}

Для многих мировых экономик сфера туризма является одним из главных приоритетов, ведь поступления в бюджеты от нее находятся на достаточно высоком уровне. Гастрономический туризм в мире и в Украине, в частности, набирает все большую популярность среди различных категорий туристов. В статье исследованы и проанализированы особенности фестивалей уличной еды как элемента туристической дестинации в современных условиях экономического развития. Обоснована необходимость научного исследования заявленной тематики. Дестинации мы рассматриваем как локационные объекты, обладающие туристско-рекреационными ресурсами, доступными благодаря наличию необходимой инфраструктуры, доводятся до потребителя в форме сформированного и подготовленного к продаже туристического продукта современными средствами маркетинговых коммуникаций в системе рычагов интегрированного управления субъектами хозяйствования. Гастрономический туризм позиционируется нами как фактор социальноэкономического развития территорий. Прослежено развитие и особенности 
фукционирования известных мировых фестивалей еды: Bacon Fest (г.Сакраменто, США), Фестиваль еды и вина (г.Мельбурн, Австралия), Peixe em Lisboa (Португалия), Brussels Food Truck Festival (г.Брюссель, Бельгия), Pizzafest (г.Неаполь, Италия), Тaste of Chicago (г.Чикаго, США), Fiesta del Marisco (г.О-Грове, Испания), Salon du chocolat (г.Париж, Франция), Ribfest Торонто (Канада), Foodies Festival Брайтон (Великобритания) и др. Подчеркнуто влияние гастрономического туризма на формирование бренда туристического места, в пространственных пределах которого он происходит. Определены основные характеристики жизненного цикла и выявлены факторы, влияющие на стадии развития фестивалей уличной еды в контексте туристической дестинации. Итак, фестивали уличной еды не только приобщают туристов к гастрономическим достижений края, но и способствуют ознакомлению с культурно-историческими, социальными, экономическими, археологическими особенностями региона.

Ключевые слова: фестиваль уличной еды, туристическая дестинация, жизненный цикл дестинации, гастрономический туризм.

\section{Solonenko Y. STREET FOOD FESTIVALS AS AN ELEMENT OF A TOURIST DESTINATION}

For many world economies, the field of tourism is one of the main priorities, because budget revenues from it are at a fairly high level. Gastronomic tourism in the world and in Ukraine, in particular, is gaining popularity among various categories of tourists. The article investigates and analyzes the features of street food festivals as an element of a tourist destination in modern conditions of economic development. The necessity of scientific research of the declared subject is substantiated. We consider destinations as location objects that have tourist and recreational resources available due to the availability of the necessary infrastructure, which are delivered to the consumer in the form of a tourist product formed and prepared for sale by modern means of marketing communications in the system of integrated business management. Gastronomic tourism is positioned by us as a factor of socio-economic development of territories. The development and peculiarities of functioning of world famous food festivals are trace: Bacon Fest (Sacramento, USA), Food and Wine Festival (Melbourne, Australia), Peixe em Lisboa (Portugal), Brussels Food Truck Festival (Brussels, Belgium), Pizzafest (Naples, Italy), Taste of Chicago (Chicago, USA), Fiesta del Marisco (O-Grove, Spain), Salon du chocolat (Paris, France), Ribfest Toronto (Canada), Foodies Festival Brighton, (UK).

The influence of gastronomic tourism on the brand formation of the tourist place within the spatial boundaries of which it takes place is emphasized. The main characteristics of the life cycle are identified and the factors influencing the stage of development of street food festivals in the context of a tourist destination are identified. Thus, street food festivals not only involve tourists in the gastronomic heritage of the region, but also contribute to the acquaintance with the cultural, historical, social, economic, archaeological features of the region.

Keywords: street food festival, tourist destination, destination life cycle, gastronomic tourism. 